\title{
Dioxins: validation of food frequency questionnaire and intake in a group of adolescents
}

\author{
Joanna Zając ${ }^{1}$, Agata Skop-Lewandowska', Jadwiga Helbin' ${ }^{1}$, Artur Potocki ${ }^{1}$ \\ 'Department of Hygiene and Dietetics, Medical College, Jagiellonian University, Krakow, Poland
}

Zając J, Skop-Lewandowska A, Helbin J, Potocki A. Dioxins: validation of food frequency questionnaire and intake in a group of adolescents. Ann Agric Environ Med. 2017; 24(3): 372-375. doi: 10.5604/12321966.1233558

\begin{abstract}
Introduction. A lot of has been heard about dioxins and dioxins-like compounds. These molecules are typically connected in public awareness with affairs. The main source of dioxins for humans is food ( $90 \%$ of typical exposition); thus, assessment of dioxins intake and monitoring of levels of dioxins in food remain an important issue.

Objective. The aim of the presented work was checking the reproducibility of the authors' semi-quantitative food frequency questionnaire, focusing on products that may contain dioxins and related compounds among adolescents. The uptake of these compounds was also assessed using obtained data. For survey purposes, an album of food products from the questionnaire was constructed.

Materials and method. A modified semi-quantitative food frequency questionnaire was constructed and distributed twice in a 2-week time span among 55, 15-year-old, students of secondary schools.

Results. The correlation coefficient for both declared frequencies and assessed amounts in the case of the majority of food items was above 0.70 . The average assessed intake of dioxins and related compounds was 1.57pgWHO-TEQ/kg body weight per day, and $1.85 \mathrm{pgWHO}-\mathrm{TEQ} / \mathrm{kg}$ body weight per day, during test and retest, respectively.

Conclusions. The modified semi-quantitative food frequency questionnaire is a reproducible tool that can be used for adolescents. Average intake in the analyzed group was lower than the Tolerable Daily Intake, but in contrast to other countries remains one of the highest intakes in a comparable age group. The main sources of dioxins exposition were fish (38\%), and meat products
\end{abstract}

\section{- Key words}

adolescents, food frequency questionnaire, validation, dioxins

\section{INTRODUCTION}

Food frequency questionnaires (FFQs) are one of the most widely used dietary assessment tools and are designed to assess usual food intake [1]. Low costs and a relatively low burden for participants make FFQs a very handy method. Eating habits during childhood and adolescence are of increasing interest because of its importance for the health of adults, especially regarding obesity, cardiovascular disease or diabetes. Food products, apart from macronutrients, can contain molecules that are classified as carcinogenic for humans. Dioxins belong to such molecules. The term 'dioxins' indicates a group of substances that are often called 'dioxins and related compounds', and consist of polychlorinated dibenzo-paradioxins (PCDDs), polychlorinated dibenzofurans (PCDFs), and polychlorinated biphenyls with dioxin-like properties (dioxin-like PCBs) [2]. In the environment, complex mixtures of these molecules are present; therefore, the concept of Toxic Equivalency Factors (TEFs) was introduced to facilitate risk assessment. TEFs indicate the concentration of mixtures of 2,3,7,8-substituted PCDDs and PCDFs, and some planar non-ortho and mono-ortho chlorine substituted DL-PCB in toxic equivalents of the most potent compound (2,3,7,8TCDD). Concentration of dioxins and similar compounds in food items is expressed in pg of Toxic Equivalent (TEQ) per gram of wet weight, or per gram of fat. TEQ is calculated by multiplying the concentration of each molecule belonging to dioxins and related compounds class with the assigned TEF [3]. The main source of dioxins and related compounds for humans is food [4]. These compounds accumulate in the body throughout life [5]. Food exposure, in the case of humans, is mainly determined by the consumption of products of animal origin, rich in fat (milk, cheese, fish, seafood or lard) due to the highly lipophilic nature of dioxins and related compounds [6]. Since the 1980s, scientists have described how culinary techniques influence the levels of dioxins and related compounds. Since then, however, no clear pattern has been found and it is suggested that not only a particular way of cooking influences the levels of dioxins and related compounds, but also specific food items typically rich in dioxins, such as fish, which can differ between species in dioxins concentration. Culinary techniques can also have different impacts on the dioxins concentration, for example, cooking can reduce the level of PCDD/PCDF in sardines or veal steak, inversely in hake and tuna, while no changes are observed in chicken meat. Fried potatoes were found to be richer in those compounds compared to raw or boiled potatoes [7]. 


\section{OBJECTIVES}

The aim of the study was to construct a semi-quantitative FFQ, tailored to products that contain dioxins and dioxinslike compounds, together with a photographic album of the portions of the product asked about in the questionnaire, and checking the reproducibility of this modified questionnaire among young students of a secondary school. The album of food products of special interest to the current study was constucted. Subsequently obtained data were used to assess dioxins and related compounds intake.

\section{MATERIALS AND METHIOD}

The study was conducted among randomly selected 15-yearold secondary school students in Krakow, after approval by the Bioethics Commission. The group consisted of 34 girls and 21 boys. A widely used method of food intake assessment - the semi-quantitative FFQ modified for dioxins assessment, consisting of 129 different questions (questions took into account different fish species or ways of preparation) was applied [8]. In the case of products that may differ in concentration of dioxins and related compounds - mainly fish, meat or other grilled or smoked food items containing fat - the participants were questioned more extensively. A detailed list of products was described previously [9]. Seven different frequencies were available for selection for each product, from 'every day' to 'less than once a month', and 'never'. Portion sizes were determined using the photographic album of food products. For more accurate assessment, the authors' album was constructed, the aim of which was to encompass the diversity of products that may contain dioxins and related compounds, especially among different species of fish.

Trained interviewers conducted the questionnaire twice in a two-week interval in September 2013, asking the participants about their usual summer consumption.

Because of the constant lack of a Polish database of concentrations of dioxins and related compounds in food products, the FDA assessment of dioxins in food was mainly used, although whenever possible, Polish data were used, such as in the case of some fish species $[10,11,12,13]$. Final concentrations were calculated for each individual and expressed in pg TEQ per kilogram of body weight per day. A medical scale was used to measure the weight of each student while wearing light clothes and without shoes.

Statistical analysis consisted of comparison between chosen frequencies and assessed amounts during the first (FFQ1) and second (FFQ2) studies using the Spermann correlation coefficient with 95\% confidence level (Tab. 1). Statistica 10.0 programme was used.

\section{RESULTS}

Coefficients below 0.7 were found for about $15 \%$ of all products and above 0.9 for about $27 \%$ - mainly products that were eaten every day, e.g. potatoes, butter, wheat bread and products, rarely consumed, such as coffee, red meat, tripe and groats. There were no statistically significant differences in assessment of boys and girls, which is why the results are presented together as a single group.
Table 1. Correlation coefficient of both frequencies and amounts declared between FFQ1 and FFQ2. Results presented only for main groups of products, including products important in the uptake of dioxins and related compounds

\begin{tabular}{|c|c|c|}
\hline \multirow{2}{*}{ Products } & \multicolumn{2}{|c|}{ Correlation coefficient $(r)$} \\
\hline & Declared frequency & Declared amount \\
\hline Eggs & 0.60 & 0.68 \\
\hline Dairy products & 0.66 & 0.80 \\
\hline Added fats & 0.71 & 0.73 \\
\hline Fast-food, casseroles & 0.74 & 0.77 \\
\hline Vegetables & 0.80 & 0.85 \\
\hline Fruits & 0.81 & 0.80 \\
\hline Fruit or/and vegetable juice & 0.92 & 0.79 \\
\hline Grain products & 0.81 & 0.81 \\
\hline Cakes, biscuits, sweet products & 0.84 & 0.69 \\
\hline Smoked cold meats & 0.65 & 0.80 \\
\hline Pork & 0.92 & 0.94 \\
\hline Beef & 0.95 & 0.92 \\
\hline Chicken & 0.78 & 0.89 \\
\hline Turkey & 0.87 & 0.74 \\
\hline Poultry,deepfried & 0.79 & 0.65 \\
\hline Fried liver & 0.78 & 0.85 \\
\hline Sausages, smoked/grilled & 0.91 & 0.85 \\
\hline Fish: Tuna & 0.77 & 0.73 \\
\hline Sardines & 0.89 & 0.85 \\
\hline Salmon & 0.67 & 0.80 \\
\hline Fish, other & 0.89 & 0.71 \\
\hline
\end{tabular}

The obtained data were used to assess the average uptake of dioxins and related compounds in the first and second questionnaires. The overall outcome was 1.57pgTEQ/ $\mathrm{kg}$ bw/day in FFQ1 and $1.85 \mathrm{pgTEQ} / \mathrm{kg}$ bw/day in FFQ2. The percentage share of average concentration of main contributors is shown in Figure 1. Table 2 presents more detailed results for the most important food groups.

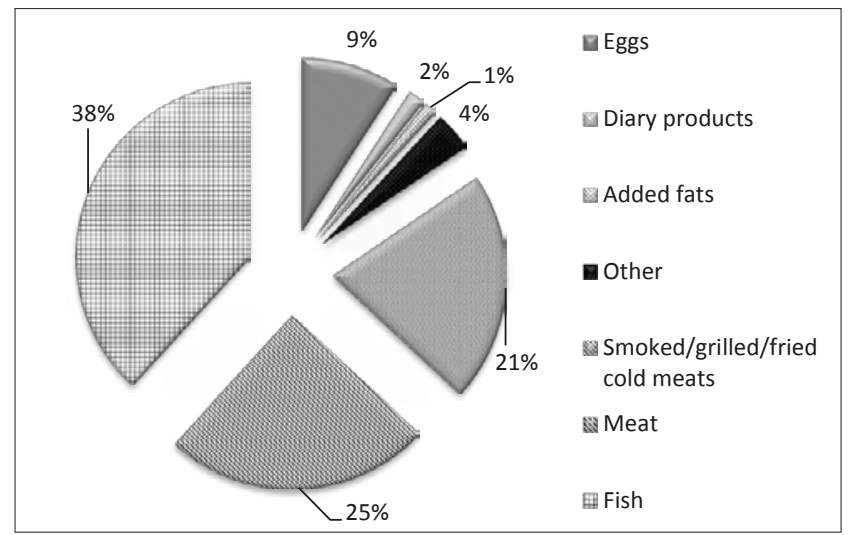

Figure 1. Percentage share of main contributors of dioxins and related compounds intake 
Table 2. Results for the most important food categories in terms of dioxins intake in FFQ1 and FFQ2

\begin{tabular}{lcccc}
\hline \multirow{2}{*}{ Products } & \multicolumn{2}{c}{ FFQ1 } & \multicolumn{3}{c}{ FFQ2 } \\
\cline { 2 - 5 } & $\begin{array}{c}\text { Average } \\
\text { [pgTEQ/kg } \\
\text { bw/day] }\end{array}$ & SD & $\begin{array}{c}\text { Average } \\
\text { [pgTEQ/kg } \\
\text { bw/day }]\end{array}$ & SD \\
\hline Eggs & 0,151 & 0,198 & 0,162 & 0,178 \\
\hline Diary products & 0,040 & 0,122 & 0,013 & 0,093 \\
\hline Added fats & 0,013 & 0,182 & 0,027 & 0,209 \\
\hline Smoked cold meat & 0.266 & 0.191 & 0.280 & 0,183 \\
\hline Pork & 0,133 & 0,182 & 0,140 & 0,169 \\
\hline Beef & 0,045 & 0,069 & 0,074 & 0,083 \\
\hline Chicken & 0,122 & 0,132 & 0,210 & 0,203 \\
\hline Turkey & 0,018 & 0,054 & 0,030 & 0,082 \\
\hline Poultry deep fried & 0,048 & 0,101 & 0,032 & 0,057 \\
\hline Fried liver & 0,054 & 0,100 & 0,071 & 0,109 \\
\hline Sausages, smoked/grilled & 0,080 & 0,202 & 0,106 & 0,209 \\
\hline Fish: tuna & 0,175 & 0,195 & 0,171 & 0,173 \\
\hline Sardines & 0,218 & 0,315 & 0,251 & 0,211 \\
\hline Salmon & 0,035 & 0,101 & 0,066 & 0.100 \\
\hline Fish: other & 0,043 & 0,140 & 0,049 & 0,137 \\
\hline Other kinds of fried/grilled food & 0,132 & 0,207 & 0,168 & 0,270 \\
\hline
\end{tabular}

\section{DISCUSSION}

The results obtained indicate high correlation coefficients between answers, both in terms of declared frequencies and amounts, which was not expected because of the number of questions in the questionnaires. According to a study by Kolodziejczyk, more food items asked about in a questionnaire were correlated with poorer correlation coefficients between test-retest [1]. Comparably high correlation coefficients were more often described for adults, e.g. by Pisani [14]. The differences could be partially caused by different timespans between the first and second questionnaire. Short time-lags $(<1$ month) between test-retest were found to be correlated with the higher correlation coefficients in the obtained results [1]. Moreover the short time span allowed the ruling-out problems with changing dietary habits or changes in seasonal availability of different products. In the presented study, the 2 -weeks delay between the 2 questionnaires could be responsible for the high correlation coefficients when comparing to other studies with a 5-6 months time span $[15,16]$. In the current study, the questionnaires completed by the participants during both surveys had no statistically significant differences. A similar phenomenon was described by Lanfer and Rockett $[17,18]$.

Due to the high correlations, data from both FFQs were used to assess the intake of dioxins and related compounds. Results from the current study (mean exposure: $1.71 \mathrm{WHO}-\mathrm{TEQ} / \mathrm{kg}$ bw/day) did not exceed the WHO threshold - Tolerable Daily Intake value (TDI: 2 pg WHOTEQ/kg b.w./day; TWI - Torelable Week Inatke - 14 pgWHOTEQ/kg b.w [19]). However, it would be advisable to lower the intake of dioxins and related compounds even more, because about $38 \%$ of participants obtained more than 2 pg WHOTEQ/kg b.w./day, and presented results are comparable with other countries and could be classified as high. In a Danish study, the mean intake of dioxins and related compounds among children between 4-14-years-old was two times lower: $0.87 \mathrm{pg} \mathrm{WHO}-\mathrm{TEQ} / \mathrm{kg}$ bw/day. In Danish group, the most important contributors were fish and fish products (about $32 \%$ in whole population), as in the presented Polish study. In second place were dairy products (about 25\%) while in case of Polish youths, these were almost on the last place (2\%) [3]. The presented data indicate a low intake of dairy products compared with results described in other Polish studies, e.g. by Wojtyła-Buciora [19].

According to data (2014) published by EFSA (European Food Safety Authority), the presented results are comparable with the mean value of dioxins and related compound intake in the Czech Republic (1.67 WHO-TEQ/kg bw/day), Italy (1.36 WHO-TEQ/kg bw/day) and Spain (1.33 WHO-TEQ/kg bw/day), while two times higher mean intake was obtained in Sweden and Cyprus (0.81 and 0.78 WHO-TEQ/kg bw/day, respectively), and about three times higher than the German intake (0.57 WHO-TEQ/kg bw/day). The main food group with the biggest relative contribution to average exposure of dioxins and related compounds is fish (63\%-38\%) and meat in case of German and Latvia adolescents [20].

As shown above, the mean dioxins and related compounds intake assessed among Polish adolescents belongs to the highest compared with other countries. Dioxins and other similar compounds are typically present in fats and fatcontaining products; thus the general tendency to choose products low in fat has one more positive aspect: a decrease in the toxic compounds normally stored in fat.

\section{CONCLUSIONS}

1) The majority of products asked about in the modified semi-quantitative food frequency questionnaire achieved correlation coefficients above 0.6 , including products that typically contain dioxins and related compounds. This allows the assessment of this questionnaire as a reproducible tool.

2) The main source of dioxins and related compounds were fish and smoked, grilled or fried meat products.

3) The assessed average dioxins intake expressed in toxic equivalent was lower than the Tolerable Daily Intake (2 pg TEQ/kg b.w./day) - 1.7 pg TEQ/kg b.w./day.

To the best of the authors' knowledge, this is the first study assessing dioxins intake among Polish adolescents.

\section{REFERENCES}

1. Kolodziejczyk JK, Merchant G, Norman GJ. Reliability and validity of child/adolescent food frequency questionnaires that assess foods and/ or food groups. J PediatrGastroenterolNutr. 2012; 55(1): 4-13.

2. Consonni D, Sindaco R, Bertazzi PA. Blood levels of dioxins, furans, dioxin-like PCBs, and TEQs in general populations: A review, 19892010. EnvInternatl. 2012; 44: 151-162.

3. Petersen A, Fromberg A, Andersen JH, Sloth JJ, Granby K, DuedahlOlesen L, Rasmussen PH, Fagt S, Cederberg TL, Christensen T, Vinggaard AM, Madsen CB, Nielsen E, Boberg J, Hansen M, Binderup M-L, Olesen PT, Kroghsbo S, Hallas-Møller T. Chemical Contaminants. Food monitoring 2004-2011. $1^{\text {st }}$ ed. Fødevareinstituttet, DanmarksTekniskeUniversitet. Soborg 2013: 57-69.

4. Charnleya G, Doullb J. Human exposure to dioxins from food, 19992002. Food ChemToxicol. 2005; 43(5): 671-679. 
5. Harden FA, Toms LML, Paepke O, Ryan JJ, Müller JF. Evaluation of age, gender and regional concentration differences for dioxin-like chemicals in the Australian population. Chemosphere. 2007; 67: S318-S324.

6. Schecter A, Birnbaum L, Ryan JJ, Constable JD. Dioxins: an overview. Environ Res. 2006; 101: 419-28.

7. Perelló G, Martí-Cid R, Castell V, Llobet JM, Domingo JL. Influence of various cooking processes on the concentrations of PCDD/PCDFs, PCBs and PCDEs in foods. Food Control. 2010; 21: 178-185.

8. Zatońska K, Campos H, Ilow R, Janik-Koncewicz K, Różańska D, Regulska-Ilow B, Połtyn-Zaradna K, Szuba A, Zatoński WA. Dietary intake and adipose tissue level of specific fatty acids in a selected group from the Lower Silesia population. Ann Agric Environ Med. 2012; 19(3): 389-394.

9. Zając J, Ostachowska-Gasior A, Lang-Młynarska D. Validation of Food Frequency Questionnaire modified for assessment of dioxins and dioxin-like compounds intake. ProblHigEpidemiol. 2013; 94(1): 111-115.

10. Usydus Z, Szlinder-Richert J, Polak-Juszczak L, Komar K, Adamczyk M, Malesa-Ciecwierz M, Ruczynska W. Fish products available in Polish market - Assessment of the nutritive value and human exposure to dioxins and other contaminants. Chemosphere. 2009; 74: 1420-1428.

11. Falandysz J, Florek A, Kulp SE, Bergqvist PA, Strandberg L, Strandberg B, Rappe C. Dioxins and furans in edible species of fish from the Gulf of Gdańsk. RoczPanstwZaklHig. 1996; 47(2): 197-204.

12. Food and Drug Administration. Dioxin Analysis Results/Exposure Estimates.http://www.fda.gov/Food/FoodborneIllnessContaminants/ ChemicalContaminants/ucm077444.htm (access: 4th June 2014).

13. Rawn DFK, Breakell K, Verigin V, Tittlemier SA, Del Gobbo L, Diamond M, Vanderlinden L, Sit D. Impacts of Cooking Technique on Polychlorinated Biphenyl and Polychlorinated Dioxins/Furan
Concentrations in Fish and Fish Products with Intake Estimates. J Agric Food Chem. 2013; 61(4): 989-997.

14. Pisani P, Faggiano F, Krogh V, Palli D, Vineis P, Berrino F. Relative validity and reproducibility of a food frequency dietary questionnaire for use in the Italian EPIC centres. Int J Epid. 1997; 26(1): S152-S160.

15. Watson JF, Collins CE, Sibbritt DW, Dibley MJ, Garg ML. Reproducibility and comparative validity of a food frequency questionnaire for Australian children and adolescents. Int J BehavNutr Phys Act. 2009; 6(1): 62-79.

16. Bilau M, Matthys C, Bellemans M, De Neve M, Willems JL, De Henauw $\mathrm{S}$. Reproducibility and relative validity of a semi-quantitative food frequency questionnaire designed for assessing the intake of dioxinlike contaminants. Env Res. 2008; 108: 327-333.

17. Lanfer A, Hebestreit A, Ahrens A, Krogh V, Sieri S, Lissner L, Eiben G, Siani A, Huybrechts I, Loit H-M, Papoutsou S, Kovács É, Pala V. Reproducibility of food consumption frequencies derived from the Children's Eating Habits Questionnaire used in the IDEFICS study. Int J Obes.2011; 35: S61-S68.

18. Rockett HR, Breitenbach M, Frazier AL, Witschi J, Wolf AM, Field AE, Colditz GA. Validation of a Youth/Adolescent Food Frequency Questionnaire. Prev Med. 1997; 26: 808-816.

19. Wojtyła-Buciora P, Stawińska-Witoszyńska B, Klimberg A, Wojtyła A, Goździewska M, Wojtyła K, Piątek J, Wojtyła C, Sygit M, Ignyś I, Marcinkowski JT. Nutrition-related health behaviors and prevalence of overweight and obesity among Polish children and adolescents. Ann Agric Environ Med. 2013; 20(2): 332-340.

20. European Food Safety Authority. Scientific Report of EFSA Update of the monitoring of levels of dioxins and PCBs in food and feed. http://www.efsa.europa.eu/en/efsajournal/pub/2832.htm(access: 4th June 2014). 